\title{
CARCINOID TUMORS - RETROSPECTIVE ANALYSIS OF PATIENTS HOSPITALIZED BETWEEN 2001 AND 2012 YEAR IN DEPARTMENT OF ENDOCRINOLOGY AND DIABETOLOGY OF LUDWIK RYDYGIER COLLEGIUM MEDICUM IN BYDGOSZCZ
}

\author{
RAKOWIAKI - ANALIZA RETROSPEKTYWNA PACJENTÓW HOSPITALIZOWANYCH \\ W KLINICE ENDOKRYNOLOGII I DIABETOLOGII COLLEGIUM MEDICUM IM. LUDWIKA \\ RYDYGIERA W BYDGOSZCZY W LATACH 2001-2012
}

Department of Endocrinology and Diabetology, Nicolaus Copernicus University in Torun, Collegium Medicum in Bydgoszcz

Head of Dept.: R. Junik, professor of medicine

\section{S u m m a r y}

Gastro-entero-pancreatic neuroendocrine neoplasms (GEP-NENs) originate from diffuse endocrine system (DES). Over $50 \%$ of diagnosed neuroendocrine neoplasms (NENs) are carcinoid tumors, secreting mainly serotonine. The incidence of carcinoids in general population is estimated to be 2.9 cases/100000 inhabitants/year.

In our study we aimed at analyzing retrospectively patients with diagnosed carcinoid tumors, hospitalized between the years 2001 and 2012 in the Department of Endocrinology and Diabetology of Nicolaus Copernicus University Collegium Medicum in Bydgoszcz.

The study group consists of 39 patients (20 women and 19 men) aged between 36 and 70, with diagnosed carcinoid. All patients have determined chromogranin A concentration
(CgA), urinary excretion of 5-hydroxyindoleacetic acid (5HIAA) in 48-hours urine sample, urinary excretion of catecholamine hormones (norepinephrine, epinephrine and dopamine), vanillylmandelic acid (VMA) and homovanillic acid (HVA) in 24-hours urine sample. Ultrasonography (US), computed tomography (CT), magnetic resonance imaging (MRI), endoscopic ultrasound (EUS) and somatostatin receptor scintigraphy (SRS) with ${ }^{99 m}$ Tc-Depreotide have been performed.

The diagnosis of the carcinoid tumor is often problematic because of its slow growth and uncharacteristic symptoms. And often the localization of the primary tumor cannot be determined. Somatostatin analogues can help to control symptoms of the carcinoid syndrome.
Guzy neuroendokrynne przewodu pokarmowego (GEPNENs) pochodzą $\mathrm{z}$ rozproszonego układu wydzielniczego (DES). Rakowiaki, wydzielające głównie serotoninę, stanowią ponad 50\% rozpoznanych guzów neuroendokrynnych. Ich występowanie w ogólnej populacji szacuje się na około 2,9 przypadków/100000 mieszkańców/rok.

W naszym badaniu przeprowadziliśmy retrospektywną analizę hospitalizowanych pacjentów w Klinice Endokry- nologii i Diabetologii Collegium Medicum im. Ludwika Rydygiera w Bydgoszczy w latach 2001-2012.

Badana grupa składała się z 39 pacjentów (20 kobiet i 19 mężczyzn) w wieku 36-70 lat, z rozpoznanym rakowiakiem. Wszystkim pacjentom oznaczono poziom chromograniny A $(\mathrm{CgA})$, wydalanie $\mathrm{z}$ moczem kwasu 5-hydroksyindolooctowego w 48-godzinnej zbiórce moczu oraz wydalanie z moczem katecholamin (noradrenalina, adrenalina i dopa- 
mina), kwasu wanilinomigdałowego (VMA) oraz kwasu homowanalinowego (HVA) w dobowej zbiórce moczu.

Wykonano badania obrazowe: ultrasonografię (USG), tomografię komputerową (TK), rezonans magnetyczny (RM), endoskopię ultrasonograficzną (EUS) oraz obrazowanie za pomocą receptorów somatostatynowych $\mathrm{z}$ zastosowaniem ${ }^{99 \mathrm{~m}}$ Tc-Depreotide.
Rozpoznanie rakowiaka jest często problematyczne z powodu jego powolnego wzrostu oraz mało charakterystycznych objawów klinicznych. Nie rzadko również nie można określić pierwotnej lokalizacji guza. Analogi somatostatyny mogą być pomocne w kontrolowaniu objawów ubocznych rakowiaka.

Key words: neuroendocrine neoplasms, carcinoid, 5-hydroxyindoleacetic acid, chromogranin A

Stowa kluczowe: guzy neuroendokrynne, rakowiaki, kwas 5-hydroksyindolooctowy, chromogranina A

\section{INTRODUCTION}

Gastro-entero-pancreatic neuroendocrine neoplasms (GEP-NENs) originate from the diffuse endocrine system (DES) cells disseminated in the gastrointestinal tract and in the pancreas [1-3]. Over $50 \%$ of diagnosed neuroendocrine neoplasms (NENs) are carcinoid, secreting mainly serotonine and found accidentally. The incidence of carcinoids in general population is estimated to be 2,9 cases $/ 100000$ inhabitants/year [4-7]. The most common localization (79\% of cases) of carcinoid is the GI tract, mainly the small intestine and appendix [8]. Outside the GI tract the most common localization is pulmonary bronchi (approximately 10\%). Rarely, carcinoid tumors are localized in other sites like pancreas, ampulla of Vater, thyroid gland, gall bladder, esophagus, thymus gland, spleen, mammary gland, ovary, uterus, testis, prostate gland, bladder, kidney [8-10]. Close to $10 \%$ of carcinoid are of unknown localization [11] and approximately $10 \%$ coexist with other tumors, like the Multiple Endocrine Neoplasia Type 1 (MEN 1) [12]. Carcinoid's peak incidence varies from decades 5 to 7 with the exception of tumors localized in the appendix, in which case the peak incidence is usually about age 35 [8].

In our study we aimed at analyzing retrospectively patients with diagnosed carcinoid tumors, hospitalized between the years 2001 and 2012 in the Department of Endocrinology and Diabetology of Ludwik Rydygier Collegium Medicum in Bydgoszcz.

\section{MATERIALS AND METHODS}

The study group consisted of 39 patients (20 women and 19 men) aged between 36 and 70 (women average age 50.2y; men - average age $47.1 \mathrm{y}$ ), with diagnosed carcinoid (secreting mainly serotonine), hospitalized between the years 2001 and 2012 in the Department of Endocrinology and Diabetology of Ludwik Rydygier Collegium Medicum in Bydgoszcz.
In all patients chromogranin $\mathrm{A}(\mathrm{Cg} \mathrm{A})$ concentration as the most commonly used test, urinary excretion of 5-hydroxyindoleacetic acid (5-HIAA) in 48-hours urine sample, urinary excretion of catecholamine hormones (norepinephrine, epinephrine and dopamine), vanillylmandelic acid (VMA) and homovanillic acid (HVA) in 24-hours urine sample have been determined.

$\mathrm{CgA}$, which is a secretory acidic protein, was determined by means of enzymatic (ELISA) method using blood serum.

The imaging research of localization were performed in all of them. We implemented, both anatomical and functional: ultrasonography (US), computed tomography (CT), magnetic resonance imaging (MRI), endoscopic ultrasound (EUS) and somatostatin receptor scintigraphy (SRS) with ${ }^{99 \mathrm{~m}} \mathrm{Tc}$ Depreotide have been performed.

In 21 cases, the patients were operated and tumors were decorticated. Definitive proof of carcinoma in these cases was obtained from histopathology of the surgical specimen. After surgical operation, stabilization of biochemical markers, was noticed. In the other cases somatostatin analogues pharmacotherapy was used to reduce secretion of hormones and control the symptoms of the disease.

All statistical analyses were performed using the Statistica 10.0 software (Statsoft Poland, Bydgoszcz). The Mann-Whitney test, a nonparametric version of the Student's t-test for independent variables, was used for the comparison. No parametric tests were used in the analyses, as for some variables the assumptions of the Student's t-test regarding normal distribution and variance were not met. The results were considered as statistically significant at $\mathrm{p}<0.05$.

\section{RESULTS}

The most common complaints are described in the figure 1 . 


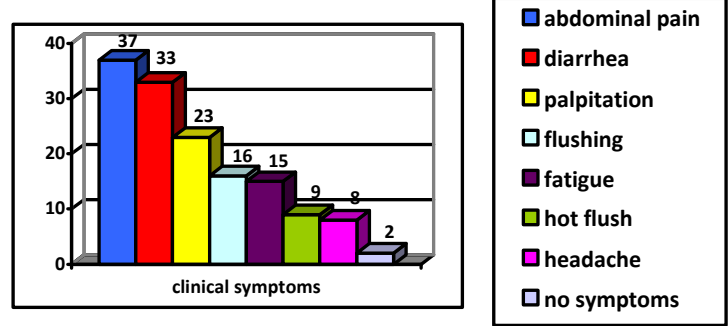

Fig. 1. Symptoms and signs reported in the study group

The most common syndromes reported in the study group were abdominal pain, diarrhea, palpitation, flushing, fatigue, hot flush and headache. Those are typical signs of carcinoid. The most common, and often the earliest, symptoms are uncomfortable flushing, diarrhea and right-sided endocardial fibrosis leading to pulmonary stenosis and tricuspid regurgitation.

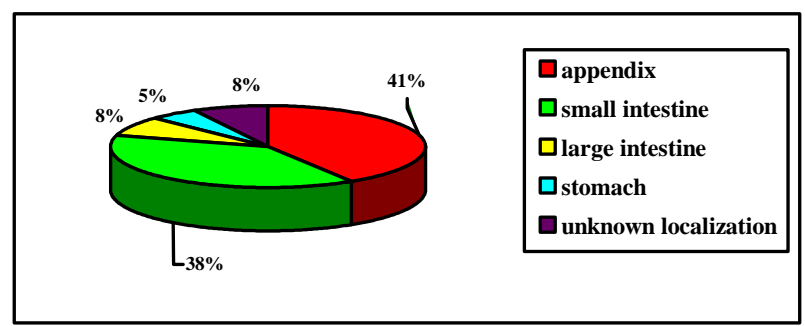

Fig. 2. Common localization of carcinoid tumors in gastrointestinal (GI) tract in the study group

Almost all of carcinoid tumors diagnosed within the 11-year period in the Department of Endocrinology and Diabetology of Ludwik Rydygier Collegium Medicum were localized in the GI tract, mainly in the appendix and small intestine (approximately 40\%). Our study shows that in 16 cases the carcinoid was in the appendix, 15 cases in small intestine and in 3 patients its localization was not determined. 6 patients of the group underwent cholecystectomy prior to the diagnose.

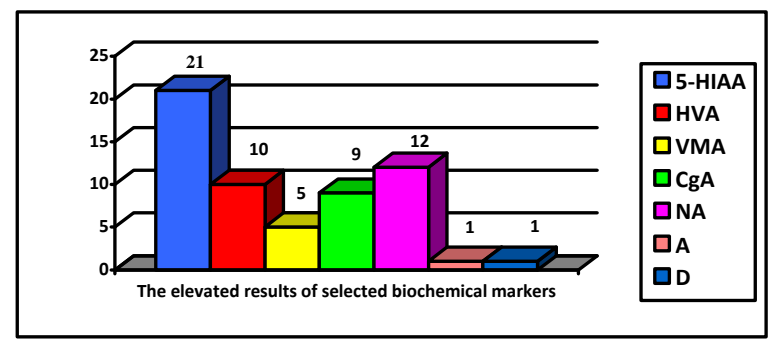

Fig. 3. Laboratory findings in the study group (carcinoids)

21 patients of the study group had a high level of 5-HIAA in 48-hour urine sample. One fourth of all cases had a high level of VMA and norepinephrine. 9 patient had positive results of the $\mathrm{CgA}$ test. The results of biochemical markers are presented in table 1 .

Table 1. Biochemical markers

Tabela 1. Markery biochemiczne

\begin{tabular}{|c|c|c|c|}
\hline Biochemical markers & $\mathrm{N}$ & Average value $\pm \mathrm{SD}$ & $\mathrm{P}$ \\
\hline 5-HIAA $[\mathrm{N}-0.7-8.2 \mathrm{mg} / \mathrm{d}]$ & 39 & $12.2 \mathrm{mg} / \mathrm{d} \pm 7.2$ & $<\mathbf{0 . 0 3 2}$ \\
\hline HVA $[\mathrm{N}-0.0-6.2 \mathrm{mg} / \mathrm{d}]$ & 39 & $6.8 \mathrm{mg} / \mathrm{d} \pm 3.2$ & $\mathrm{NS}$ \\
\hline VMA[N $-1.8-6.7 \mathrm{mg} / \mathrm{d}]$ & 39 & $5.9 \mathrm{mg} / \mathrm{d} \pm 2.7$ & $\mathrm{NS}$ \\
\hline $\mathrm{CgA}[\mathrm{N}-2.0-18.0 \mathrm{U} / \mathrm{l}]$ & 39 & $16.3 \mathrm{U} / \mathrm{l} \pm 8.3$ & $\mathrm{NS}$ \\
\hline NA $[\mathrm{N}-12.1-90.0 \mu \mathrm{g} / 24 \mathrm{~h}]$ & 39 & $84.2 \mu \mathrm{g} / 24 \mathrm{~h} \pm 26.2$ & $\mathrm{NS}$ \\
\hline A $[\mathrm{N}-1.7-22.4 \mu \mathrm{g} / 24 \mathrm{~h}]$ & 39 & $15.8 \mu \mathrm{g} / 24 \mathrm{~h} \pm 13.1$ & $\mathrm{NS}$ \\
\hline D $[\mathrm{N}-0.0-498.0 \mu \mathrm{g} / 24 \mathrm{~h}]$ & 39 & $233.6 \mu \mathrm{g} / 24 \mathrm{~h} \pm 112.2$ & $\mathrm{NS}$ \\
\hline
\end{tabular}

The results of imaging examination were presented in table 2.

Table 2. Imaging methods

Tabela 2. Metody obrazowania

\begin{tabular}{|c|c|c|}
\hline $\begin{array}{l}\text { Imaging } \\
\text { methods }\end{array}$ & $\mathrm{N}(\%)$ & Visualized changes of carcinoid (\%) \\
\hline US & $39 / 39(100)$ & $6 / 39(15.3)$ \\
\hline CT & $28 / 39(72)$ & $24 / 28(85.8)$ \\
\hline MRI & $12 / 39(31)$ & $4 / 12(33.3)$ \\
\hline EUS & $16 / 39(41)$ & $13 / 16(81.3)$ \\
\hline SRS & $14 / 39(36)$ & $11 / 14(78.6)$ \\
\hline
\end{tabular}

Classical imaging methods such as US, CT and MRI play an important role in planning a surgical treatment. EUS examination is mainly useful for the diagnosis of pancreatic NENs because of their small size and is more sensitive than CT.

Only in one patients with diagnosed insulinoma a single tumor $(2 \mathrm{~cm})$, situated on a border of head and corpus of pancreas, was localized with the use of the computed tomography. Also in two of other patients with the use of the endoscopic ultrasonography an insulinoma was recognized.

\section{DISCUSSION}

Recently, an increase in the incidence of gastrointestinal NENs has been observed. The carcinoids are most frequently found accidentally, mainly during a surgical procedure. Sometimes metastases, mainly to liver, are visualized first.

There are isolated reports about the coexistence of carcinoid tumors and primary biliary cirrhosis, primary idiopathic thrombocytopenia (ITP), systemic sclerosis (SSc), systemic lupus erythematosus (SLE), rheumatoid arthritis, polymyositis (PM) and 
dermatomyositis (DN) [10,13]. Carcinoid tumors are 15 times more frequent in patients with Crohn's disease, as evidenced by some publications. West et al. estimated that carcinoid tumors occur in $3.6 \%$ cases of Crohn's disease [14].

According to some authors, cholecystectomy is also a risk factor of NEN's development [15].

In the early stage symptoms mentioned above are occasional, but with the progression of the disease they become more and more frequent. Gastrointestinal signs as diarrhea, abdominal pain or malabsorption syndrome result from the high level of serotonin, which leads to mesentery fibrosis, ischemic and motoric bowel's dysfunction. On the other hand, the intestinal carcinoids do not usually produce the symptoms. Metabolic products released by it are destroyed by liver enzymes in the portal circulation. The estimated time from the first occurrence of the signs to the diagnosis of the disease is from 2 to 9 years [16.17]. Primary carcinoid tumors located outside the GI tract and carcinoid hepatic metastases induce symptoms, mainly bronchiectasis, lung collapse and other atypical symptoms like Cushing's syndrome caused by secretion of ACTH [9.10]. Sometimes there are neurological symptoms like convulsions, faintness without intracranial changes in brain CT [18]. 90\% of carcinoid tumors are malignant, but due to the slow progression metastatic disease is relatively rare and appears after long-term illness. Carcinoid metastases spread mostly to liver, lungs, lymph nodes, pancreas, omentum, rarely to bones, brain, skin, muscles and spleen [19-21].

Patients hospitalized in the Department of Endocrinology and Diabetology had symptoms of the carcinoid syndrome, but only 2 of them underwent liver resection, and another 4 of them had positive results of the SRS with ${ }^{99 \mathrm{~m}} \mathrm{Tc}$-Depreotide. The rest of the patients had no signs of metastases. No case of endocardial fibrosis was found in the whole group.

Recently, there has been much progress in the diagnosis of NEN's due to new, more sensitive methods. Biochemical tests are essential in the diagnosis of carcinoid, especially the urinary excretion of 5-hydroxyindoleacetic acid (5-HIAA) in 48-hour urine sample, urinary excretion of catecholamine hormones (norepinephrine, epinephrine and dopamine), vanillylmandelic acid (VMA) and homovanillic acid (HVA) in 24-hours urine sample, serum level of chromogranin A ( $\mathrm{CgA})$, neuron-specific enolase (NSE) and human chorionic gonadotrophin. It should be remembered that carcinoids of the large intestine ending do not produce serotonin, which makes the excretion of 5-HIAA useless [1.7].

$\mathrm{CgA}$ is sensitive, but is an unspecific marker of GEP-NENs. It is excreted from different kinds of NENs. The carcinoid syndrome is characterized by particularly high levels of chromogranin A (100-1000 above normal). $\mathrm{CgA}$ is an important marker used to monitor the progress and treatment of GEPs. It is also an independent prognostic factor of life expectancy with NENs originated from midgut.

NENs show the diversity of differentiation, grading, TNM staging, localization and course of the disease. And the diagnosis requires different methods of imaging. Diagnostic imaging of NENs is difficult due to their small size and often atypical location. Therefore, we have to use both anatomical and functional methods such as: ultrasonography, computed tomography and magnetic resonance imaging [5], (these methods have a detection rate of 40 to $60 \%$ with regard to primary tumors and $80 \%$ for metastases [22]) and endoscopic ultrasound (EUS), contrast-enhanced US (CEUS), intraoperative US (IOUS), endoscopy and venous catheterization [7,23]. Endoscopy of the GI tract is one of the best, invaluable diagnostic tools for locating GEP-NENs and is often the first procedure to be used with suspected or diagnosed NEN. Diagnostic EUS very often allows localizing NENs that were not identified by other radiologic imaging methods. It is particularly successful in identification of pancreatic-NENs due to the unique proximity of the echoendoscope to the pancreas. With the use of EUS, pancreatic lesions as small as 2 to $5 \mathrm{~mm}$ can be detected. Computed tomography examination is the standard method in assessment of the location of tumour foci and determination of the NEN stage [24]. It also is used to monitor the effects of treatment. In our group 16 patients had EUS, 28 patients had CT and 12 MRI. We have also a non-invasive examination of the small intestine called Video Capsule Endoscopy (VCE). This a new technique, allowing appointment of the small intestine mucosa along its entire length [1]. The limitation of this technique is the run-time (eight hours) of the battery inside the capsule.

The most sensitive method of the diagnostic imaging of NENs is somatostatin receptor scintigraphy (SRS). A high incidence and density of somatostatin receptors (SSTRs) are found in GEP-NENs [3]. Five types of SSTRs have been found and cloned so far. In 
the majority of NENs (above 80\%) SSTR2 is expressed and SRS with [ ${ }^{111}$ In-DTPA] Octreotide or ${ }^{99 \mathrm{~m}} \mathrm{Tc}$-Depreotide can be used. Sensitivity is $90 \%$ and specificity is $83 \%$ for most types and locations of GEP NENs $[7,23,25]$. It must be considered that falsepositive results of SRS have been reported. In the study group 3 out of 14 patients with positive SRS had negative histopathological diagnosis.

Surgery is a treatment of choice for carcinoid and requires total tumor resection within safety margins and lymph nodes dissection. It is also used for reducing tumor mass (cytoreductive therapy) and as a palliative therapy (improvement of the quality of life). In 12 patients from the study group appendectomy was performed, in 2 - right-sided hemicolectomy, one patient underwent partial gastrectomy. In 3 patients localization was not determined.

When surgery is not curative, the biotherapy and/or chemotherapy for neuroendocrine tumors is recommended. 5 patients of our group received such treatment (3 patients in whom the localization of the primary tumor was unknown and 2 after right-sided hemicolectomy). Somatostatin analogues (octreotide and lanreotide are more resistant for enzymatic degradation and have longer biological half-life than native somatostatin) are golden standard of treating GEP-NETs and might block the release of various agents like serotonin or 5-HIAA and thereby, reduce such symptoms like diarrhea. Their action is mediated through SST receptors (mainly SSTR2, SSTR1 and STTR5). A high density of somatostatin receptors is found in neuroendocrine tumors of bronchi, stomach and small intestine $[12,26]$. Octreotide has a high affinity to SSTR2, lanreotide and vapreotide to SSTR1 and STTR5.

We can also use interferon alfa (INF- $\alpha$ ), but due to a larger number of adverse reactions, it is the secondline treatment.

\section{CONCLUSION}

The diagnosis of the carcinoid neoplasm is very problematic because of its slow growth and uncharacteristic symptoms. However, once the diagnosis is set, we have the tools to treat it.

\section{REFERENCES}

1. Kos-Kudła B, Blicharz-Dorniak J, Handkiewicz-Junak D et al. Diagnostic and therapeutic guidelines for gastroentero-pancreatic neuroendocrine neoplasms (recommended by the Polish Network of Neuroendocrine Tumors). Polish J Endocrinol 2013; 64: 418-443.

2. Kos-Kudła B, Bolanowski M, Handkiewicz-Junak D et al. Diagnostic and therapeutic guidelines for gastrointestinal neuroendocrine tumors (recommended by the Polish Network of Neuroendocrine Tumors). Polish J Endocrinol 2008; 59: 41-56.

3. Plockinger U, Rindi G, Arnold R et al. Guidelines for the diagnosis and treatment of neuroendocrine gastrointestinal tumours. Neuroendocrinology 2004; 80: 394-424.

4. Vinik A, Feliberti E, Perry R et al. Carcinoid tumors. Diffuse hormonal system. Endotext com, South Dartmouth 2008.

5. Szczeblowska D,. Diagnostics and treatment of neuroendocrine tumors of the digestive tract in the light of the present standards. Pol Merk. Lek. 2007; 131: 437441.

6. Taal BG, Smith M. Developments in diagnosis and treatment of metastatic midgut carcinoid tumors. Minerva Gastroenterol Dietol. 2005; 51: 335-

7. Kos-Kudła B, Zemczak A. Contemporary methods of diagnosis and treatment of neuroendocrine gastrointestinal tumors. Pol J Endocrinol 2006; 57: 174186.

8. Mielczarek P, Bagłaj M, Bogdanowicz E. Carcinoid of the appendix. Adv. Clin. Exp. Med 2003; 12: 825-832.

9. Vigg A, Mantri S, Swarnalata G et al. Atypical carcinoid tumour. Indian J Chest Dis Allied Sci 2005; 47: 213-215.

10. Modrzejewska A, Śledź M, Chęciński P et al. Carcinoid tumour of the gallbladder: laparoscopic resection and review of the literature. Videosergery and other miniinvasive techniques 2009; 4: 72-75.

11. Białecki J, Libiszewski M, Drozda R et al. Treatment with videoscopic technique in a case of appendix vermiformis carcinoid - case study. Wideochirurgia i inne techniki małoinwazyjne. 2008; 10: 146-150.

12. Krysiak R, Okopień B, Herman ZS. Current concepts on diagnosis and treatment of carcinoid. Przegląd Lekarski 2007; 64: 103-110.

13. Trzcińska-Butkiewicz B, Łukjanowicz M, Brzosko M. Carcinoid of the pancreas with metastases to liver of young patient with systemic lapus erythematosus. Reumatologia 2007; 45: 436-438.

14. West NE, Wise PE, Herline AJ et al. Carcinoid tumors are 15 times more common in patients with Crohn's disease. Inflamm Bowel Dis 2007; 13: 1129-1134.

15. Kluciński A, Pawłowski W, Krasnodębski IW. Synchronus intestinal tumors - coexisting adenocarcinoma transverse colon and small intestine carcinoid. Przegląd Gastroenterologiczny 2006; 1: 126128.

16. Wisłowska M, Klimowicz K. Neuroendocrine tumor of RA patient - a case report. Reumatologia 2006; 44: 5659.

17. Sinha V, Dyer P, Roy-Choudhury $S$ et al. Case of carcinoid crisis following a fine - needle biopsy of hepatic metastasis. Eu J of Gastroenterology and Hepatology 2009; 21: 101-103. 
18. Erlich R, Morrison C, Kim B et al. ANNA-2: an antibody associated with paraneoplastic opsoclonus in a patient with large-cell carcinoma of the lung with neuroendocrine features-correlation of clinical improvement with tumor response. Cancer Invest 2004; 22: $257-261$.

19. Rymarczyk G, Hartleb M, Nowak A et al. Carcinoids of the digestive tract. Gastroenterologia Polska 2000; 7: 97102.

20. Blochin E, Stein J, Wang N S. Atypical carcinoid metastasis to the skin. Am J Dermatopathol 2010; 32: 735-739.

21. Tiktinsky E, Horne T, Agranovich S et al. Intramuscular metastasis of the carcinoid tumor. A rare manifestation. Clinical Nuclear Medicine 2008; 33: 565-566.

22. Bolanowski M, Jarząb B, Handkiewicz-Junak D et al. Neuroendocrine tumors of the small intestine and the appendix - management guidelines (recommended by the Polish Network of Neuroendocrine Tumors). Pol J Endocrinol 2008; 59: 87-96.

23. Ramage JK, Davies AHG, Ardill J et al. Guidelines for the management of gastroenteropancreatic neuroendocrine (including carcinoid) tumours 2005; 54 : $1-16$.
24. Nasierowska-Guttmejer A, Malinowska M. Guzy neuroendokrynne układu pokarmowego (GEP/NET) dyskusja wokół nazewnictwa i klasyfikacji. Przegl Gastroenterol 2006; 1: 1-4.

25. Langfort R, Rudziński P, Burakowska B. Pulmonary neuroendocrine tumors. The spectrum of histologic subtypes and current concept on diagnosis and treatment. Pneumonologia i Alergologia Polska 2010; 78: 33-46.

26. Deptała A, Asendrych A, Omyła-Staszewska J et al. Systemic therapy in the treatment of gastroenteropancreatic neuroendocrine tumors. Przegląd Gastroenterologiczny 2006; 1: 10-15.

Address for correspondence:

dr n. med. Marcin Gierach

Department of Endocrinology and Diabetology of Ludwik Rydygier

Collegium Medicum in Bydgoszcz, University of Nicolaus Copernicus in Torun

ul. M. Skłodowskiej-Curie 9

85-094 Bydgoszcz POLAND

tel./fax (+48)(052) 5854240

e-mail: marcin_gierach@wp.pl

Received: 4.11.2013

Accepted for publication: 26.08.2014 